\title{
The Stone Pit
}

\author{
Eva Elias
}

\begin{abstract}
La carrière
«Le marbre que tu utilises a une belle texture», remarque le peintre qui visite le studio de la sculpteure. Mais les corps de fermmes - qui se meuvent librement sur ses canevas à lui-fuient son ciseau. Elle est hantée par l'habilité qu'il a de créer alors que son bloc de pierre refuse de lui révéler les courbes et les creux dont elle est à la recherche. Tout ce qui est exposé dans son studio, c'est la matérialité du marbre. Comparant la luminosité et $l^{\prime}$ espace de son studio à ceux du peintre, à la production artistique «masculine» et «féminine», ce texte pose des questions sur la désincarnation de la sculpture des femmes. A la toute fin, la sculpteure en vient à mettre en jeu son propre corps pour le libérer de la pierre qui le retient.
\end{abstract}

"The marble you use has a beautiful texture."

The marble I use is a fine grained white stone of frustrating purity.

As usual, they came at five. The hour when light is perfectly distributed in the studio, when corners become dramatically alive with shadows and when sunbeams, falling unevenly on the shelved walls, give the white stone the relief and depth it lacks in the morning's stark light.

They file in reverently, unsure of where they should start the tour. Uncomfortable in the hushed ambiance, they look around silently, then the whispering begins. At the far end of the long room, sitting on my divan, I wait with growing impatience as bits of words and phrases reach me like interferences on a bad telephone line.

As they get close to the work table, they group again. Abashed? Intrigued? And: "What a lovely view!"

"I love those old bay windows."

"There is so little green left in the city, you are lucky to have such beautiful trees around you."

At last. I don't know who is more relieved, and I smile.

With a carefully studied movement, I invite them to join me, and as 
they are seating themselves on the fine workmanship of rigid red chairs, I offer them liqueurs.

"I'm so sorry, I don't have any other kind of drink here, not even tea or coffee."

My hollow apologies are drowned in exclamations of delight. It took over a year to realize that only liqueurs will make them leave quickly enough. All other drinks seemed to call for refills or second rounds, which engendered long evenings of smoke and party hubbub, where everyone seemed comfortable except me, and where with me, everything in the studio lost its life to the warm engulfing human body.

It had to be reversed. In front of my mirror I learnt gestures and postures that are seemingly normal, yet from which transpire a tension that is painful to watch.

But something went wrong today. And I knew it would as soon as I saw him coming in with them. I was sure he would come one day, since that afternoon in his studio when I went to look at his latest paintings. When in a small room at the end of a long corridor, where the thin walls carried the sound of a glaring T.V. and children playing, under the light of a naked bulb, I saw myself disintegrating as, one by one, he pulled out his paintings and turned them to face my eyes.

On his canvasses moved the women who hide in my blocks of stone, eluding my chisel. I saw the bodies I was unable to free, an arm reaching towards stars, a neck bent in abandon, a hand gently resting on the roundness of a breast and feet dancing, drawing circles of ecstasy in grains of sand.

Because he came today, did not sit on the fifth red chair, took his glass of benedictine, walked back to the worktable, examined the tools, sat on the window sill and became larger and larger in the light of a sinking sun; because he said: "The marble you use has a beautiful texture," a scream explodes, reverberating against the maladjusted mask, as I close the door on their backs.

How long have I been standing in front of the worktable, looking at the block of stone. It was now dark outside, the only light is coming from the street lamp facing the window. And in this new pattern of light, the room takes on different dimensions. The shelves blend with walls, and illuminated parts of marble create an alien shape, a sculpture.

I hold the mallet and chisel. I hit the block of stone, shattering the silence. Fragments of marble sparkle around me in bursts. I shape curves that disappear, hollows that are evened, and I polish another perfect 
sphere. Behind the opacity of the pure white stone, only I can see the maze of moving planes intersecting.

I move around the studio removing every lampshade, lighting up every single bulb. I paste up paper on every mirror and glass pane, cover furniture with sheets, filling gaps with newspapers, blocking holes with construction paper. Carefully, I objectify space then stand in the middle of a room where my voice does not echo.

I shift into first like I slammed the door of the studio.

I am the anonymous bubble gliding on the black asphalt. With sharp wheel turns I jostle out and break away from the ominous hovering predators shadowing the horizon with heavy breath. Exuberant, I race off and smoothly swish against the wind.

A hole. Paranoid, I dodge.

A stone. Megalomaniac, I center myself and pass over it untouched.

Rails, infinitely metallic, carrying the rhythmic thunder of perpetual motion. The train, a crushing black monster, approaches the crossing. I stare for an instant, and push down on the gas pedal. Did it stop, or did I fly over it? The rabid pulse slowly subsides, sweat leaves me cold and drained. I search around me for the life I have not risked. 